\title{
ANALYSIS OF ISLAMIC BANK INFLUENCE ON AGRICULTURAL FINANCING SECTOR PERIOD 2014-2016
}

\author{
Tari Lestari \\ ${ }^{1}$ Faculty of Islamic Studies, Universitas Muhammadiyah \\ Surakarta \\ email: tharee96@gmail.com
}

\begin{abstract}
One main problem that Indonesia's agricultural sector faces is limited financial acces. This research tries to analyze Islamic Banking influence on agricultural financing sector in Indonesia. It utilizes monthly data of Islamic banking statistic from January 2014 until December 2016. This study conducts OLS (Ordinary Least Squares) as its analytical method to intrepret the data analysis. The finding of this paper shows that the incentive of Islamic Bank Indonesia Certificate (SBIS), third party fund, inflation, Non Performing Financing influence agricultural financing significantly. But, interest rate is not affecting agricultural financing. This research suggests the increase in agricultural financing proportion for agriculture should be in accordance with increase in total deposit value. This finding recommends improvement of the human resources competency in agriculture sector as well as strengthening instruments of Islamic financing policy.
\end{abstract}

Keywords: Islamic Bank, Agriculture, Financing, Agricultrural Sector

\section{INTRODUCTION}

As one of the sectors that play an important role in the national economy, the agricultural sector still faces several obstacles including the lack of access to financing sources, therefore, there 
is a need for a financing model that is able to provide stimulus to agricultural businesses to increase their production, the majority of farmers in Indonesia who only have small-scale businesses, namely the agricultural sector in general still rely on their own capital in the development of their business (Beik 2013).

As an agricultural country, the agricultural sector has a very strategic role in national development. The importance of the agricultural sector among other sectors is as a source of livelihood for the majority of the population in Indonesia. It has also contribution to GDP, the exports, industrial raw materials and the provision of food and nutrition. The agricultural sector also proved to be able to support the national economy in the event of an economic crisis (Ashari 2005). Although very strategic, the agricultural sector is often faced with many problems, especially weak capital as an essential element in increasing the production and living tariffs of rural communities, the lack of capital can limit the movement of this sector.

In addition, the problem of bankability and perceptions of banks that consider agriculture as a high risk industry are the two factors that cause low rates of lending and bank financing in the agricultural sector. While the weak access of small farmers to banking financial institutions is caused by non-simple procedures and requirements that must be met by farmers. On the other hand, the banks themselves are less interested in financing the agricultural sector which is considered high risk, both due to natural disturbances such as floods, droughts, pest and plant diseases, and price fluctuations (Beik 2013). For this reason, it is necessary to develop appropriate and responsive strategies in managing the development of the agricultural sector so that Indonesia has a strong bargaining position. Agricultural 
development is directed to increase farmers' income through increased farming productivity and value-added products, as well as agricultural product distribution. This aspect requires funding in the form of financial support in the form of working capital.

Agricultural financing in conventional banks is considered to be less effective because of the interest set by the government. This makes farmers as additional returns, the financing gap between the borrower and the funder where the two parties are not in full synergy, each moves itself in a different calculation because the creditor is using more monetary sector analysis while the debtor in the real sector activities. The banking sector has not provided optimal support in increasing the amount of lending and the ease of obtaining capital loans to the agricultural sector, especially small farmers. Therefore an alternative source of financing is needed for the agricultural sector. One alternative that can be developed is financing through Islamic banking. With the characteristics of Islamic banking based on the real sector, the pattern of Islamic financing for the agricultural sector is expected to be well developed (Nasution 2006).

In the world of banking itself consists of two forms, namely conventional and Islamic banks. The conventional bank in its activities uses an interest system that is inspired by the capitalist economic system by attracting business profits mainly from credit interest which is utilized through public savings funds which are then borrowed back with additional interest, while the Islamic banking principles are based on Islamic law and does not recognize interest but profit sharing.

The development of Islamic banking in Indonesia seems 
to be rapid, this can be seen from the data published by Bank Indonesia. In July 2010 the number of Islamic banks reached 43 units consisting of 10 Islamic Commercial Banks and 33 Sharia Business Units. In addition, the number of Sharia Rural Banks (BPRS) has reached 146 units in the same period and the number of sharia banking office networks reached 1,640 offices with better growth performance of Islamic banks. This is evidenced by the disbursement of financing by Islamic banks that consistently continues to increase to reach 57.633 trillion to several economic sectors such as agriculture, forestry, agricultural facilities, mining, industry, business services, to social / community services (Otoritas Jasa Keuangan 2010).

Tabel 1.1

Islamic Banking Financing based on the Bussiness Field of the Year 2014-2016 (in billion rupiah).

\begin{tabular}{lccc}
\hline \multicolumn{1}{c}{ Financing Sectors } & \multicolumn{3}{c}{ Year } \\
\cline { 2 - 4 } & $\mathbf{2 0 1 4}$ & $\mathbf{2 0 1 5}$ & $\mathbf{2 0 1 6}$ \\
\hline Agriculture, Animal Husbandry, Forestry & 4.965 & 7.950 & 8.531 \\
Fisheries & 714 & 1.198 & 1.405 \\
Mining and Quarrying & 4.597 & 6.145 & 6.604 \\
Processing Induyst & 13.300 & 17.982 & 19.745 \\
Electricity, Gas, and Water & 5.492 & 6.427 & 8.117 \\
Construction & 11.669 & 11.193 & 14.435 \\
Wholesale and Retail Trade & 22.732 & 25.993 & 30.319 \\
Food and Beverage Accomodation and & 1.555 & 2.101 & 3.043 \\
Provision & & & \\
\hline Transportation, Warehouse, & 12.192 & 11.072 & 10.921 \\
Communication & 16.828 & 19.184 & 18.948 \\
Financial Intermediaries & & &
\end{tabular}




\begin{tabular}{lccc}
\hline \multicolumn{1}{c}{ Financing Sectors } & \multicolumn{3}{c}{ Year } \\
\cline { 2 - 4 } & $\mathbf{2 0 1 4}$ & $\mathbf{2 0 1 5}$ & $\mathbf{2 0 1 6}$ \\
\hline $\begin{array}{l}\text { Real Estate, Rental Business and } \\
\text { Corporate Services }\end{array}$ & 7.643 & 9.365 & 12.797 \\
$\begin{array}{l}\text { Community Service, Social Culture, } \\
\text { Entertaintment }\end{array}$ & 6.757 & 4.600 & 4.617 \\
Others & 6.944 & 2.147 & 7.60 \\
\hline
\end{tabular}

Source : Islamic Banking Statitistic (organized)

Table 1.1 indicates financing inequality that occurs is not solely due to the low ability of the agricultural sector to return financing, but rather due to the very low alignments in the agricultural sector and the very rigid rules of credit, especially for agribusiness farmers. The concept of profit sharing is the right scheme for the economic activities of farmers. If the orientation of Islamic banks to financing the real sector businesses, it would be better if the business in the agricultural sector gets a large portion.

Islamic banks have a strategic role as an intermediary institution between the money market and the real economy business world, especially the agricultural sector.According to research conducted by Ashari (2005), Islamic financing products that can be applied to agribusiness businesses including Mud\} a $>$ rabah, Musha $>$ rakah, muzara'ah, musa $>$ qah, bay mura $>b a\{h\}$ ah, bay is $\{\mathrm{t}$ \{isna', bay salam, and pawning (rahn). The form of financing and its financing unit can be adjusted to the needs based on the process / sub system.

The economic condition that always attracts the attention of banks in channeling financing is the inflation rate, because inflation generally means an increase in the general price level of goods or commodities and services during a certain period. Inflation also has a number of adverse effects on individuals, 
society and overall economic activities, therefore Bank Indonesia, which has the task of establishing and implementing monetary policy in order to support its function, Bank Indonesia can carry out monetary control based on Islamic principles through open market operations.

Bank Indonesia Sharia Certificate referred to SBIS, which is a securities based on Islamic principles with short-term maturity in rupiah currency issued by Bank Indonesia. This SBIS will be an alternative for Islamic banks to secure their funds. Because if there is inflation, people will prefer to save their money compared to taking financing in Islamic banks (Dahlan 2015). In addition to financing Islamic banking influenced by Inflation factors and SBIS Bonuses, the bank's business in raising funds greatly influences bank development. In seeking for funding sources, banks must consider factors such as the level of ease to obtain the source of funds or the costs incurred by the bank. Sources of funds from the community are the main source of funds for banks. This source of funds is easy to find and available in large numbers in the community. Banks only need to attract the public by providing promos or providing products that are easy to terms and conditions.

The existence of credit interest rates is a position that is no less important than third party funds. When interest rates rise, demand for conventional credit will decline. The relationship between conventional banking credit and Islamic banking financing is unidirectional, so the decline in conventional credit demand will reduce demand in Islamic banking. The decline in Islamic financing has resulted in a decline in financing of the agricultural sector. Furthermore, the high NPF (Non Performing Financing) results in a decrease in financing of Islamic banks and 
will also impact on agricultural financing.

This research is conducted to analyze the effect of simultaneous bonus of Bank Indonesia Sharia Certificates, third party funds, inflation, Non Performing Financing and loan interest rates on Sharia Bank financing in the agricultural sector in Indonesia. This research tries to describe the effect of partial bonuses on Bank Indonesia Sharia Certificates, Third Party Funds, inflation, Non Performing Financing and loan interest rates on Sharia Bank financing in the agricultural sector in Indonesia.

This study is expected to be used as an illustration of the condition of whether an Islamic bank possibly become provider of funds for the agricultural sector. This study can contribute consideration in making decisions to maximize the company's performance in terms of financing, especially in agricultural financing.

\section{LITERATURE REVIEW}

\section{Definition of Islamic Banking}

The Bank is a financial institution, which is an entity that functions as a financial intermediary or financial intermediary of two parties, namely the party that is over-funded and the party that is under-funded. As an important institution in the community, the bank is a financial institution whose main business provides credit and services in payment traffic and money circulation (Sinungan 1993). Bank is simply defined as financial institution whose business activities are collecting funds from the community and channeling the funds back to the community and providing other bank services (Kasmir 2010).

Islamic banks are banks that are in their activities, both fund 
raising and in the context of channeling funds to provide and impose compensation on the basis of sharia principles, namely buying and selling and profit sharing. Islamic banks are referred to as banks without interest because in raising funds do not provide interest payments, and in loans are not charged interest. Islamic banks are referred to as banks without interest because in raising funds do not provide interest payments, and in loans are not charged interest (Herman 2006).

According to Muhammad (2005) Islamic banks are banks that operate without relying on interest. Islamic banks or commonly referred to as interest-free banks are financial / banking institutions whose operations and products are developed based on the Al-Quran and Sunnah. In other words, Islamic banks are financial institutions whose main business provides financing and other services in payment traffic as well as circulation of money whose operations are adjusted to Islamic law. Islamic banks are banks that carry out their business activities based on Islamic principles, namely the rules of interbank agreements with other parties (customers) based on Islamic law. So the difference between the Islamic banks with a conventional bank is located on the basic principle of operation that does not use interest, but use the principle of sharing, buying and selling and other principles in accordance with the Islamic Shari'a, because the flower is believed to contain elements of usury is forbidden (prohibited) by Islam.(Rivai 2007).

\section{Influence of Islamic Banks on The Agricultural Financing sector in Indonesia}

At present the national bank's alignment with the agricultural 
sector is very low. Based on BI data, national bank lending as of March 2007, only 5.4 percent of total loans amounted to 800.337 billion. Furthermore, credit is dominated by the services sector by 37.21 percent, industrial sector 22.93 percent, trade 20.93 percent. Therefore, the role of Islamic banking is expected to drive the agricultural sector in Indonesia.

Islamic banks are more appropriate to play a role in agriculture than conventional banks. This is based on several things. First, because philosophically, Islamic banking has strong ties with the agricultural sector. Farmers who have been accustomed to profit sharing systems such as maro, gaduhan and others make it easier for Islamic banks to enter the heart of the agricultural sector. Second, the Islamic system is actually more in line with the characteristics of farmers and agriculture in Indonesia compared to the interest system. In the Islamic system, what is required is the ability of farmers to produce agricultural products. Third, increasing bank services to the agricultural sector by expanding networks through collaboration with various microfinance institutions. Fourth, developing Muzaraah products as one of the instruments in the financing of the agricultural sector.

\section{Role of Agriculture Industry}

Agricultural Agriculture Sector is an industry that organizes production factors (land, minerals, capital, management, labor) to produce and market food and fiber (Purwaningsih 2017) . For a country that will carry out its economic development, there are a number of choices that will certainly be adopted. There is a country that in its economic development relies on the industrial sector and then follows other sectors. There are countries that prioritize the agricultural sector than others. And there are also 
countries that choose a combined alternative, namely balancing between the industrial sector and the agricultural sector. In addition, in reality agriculture is indeed an important sector in the Indonesian economy because up to now around 63 percent of the population is foraging in the agricultural sector (Prayitno 1985). The agricultural sector can be classified into several sub-sectors, namely the food crop sub-sector, the plantation sub-sector, the livestock sub-sector and the fisheries subsector.

\section{Certificate of Islamic Indonesia Bank (SBIS)}

Bank Indonesia legislation Number 10/11 / PBI dated March 31, 2008 concerning Bank Indonesia Sharia Certificates. Bank Indonesia Sharia Certificates (SBIS) are securities based on short-term Sharia Principles in rupiah currency issued by Bank Indonesia.

\section{Third Party Funds (TPF)}

The bank's efforts in raising funds dominantly affect the development of the bank. In finding sources of bank funds, banks must consider factors such as the level of ease in obtaining the source of funds or the costs incurred by the bank to obtain it. Sources of funds from the community are the main source of funds for banks. This source of funds is easy to find and is also available in large numbers in the community and the conditions are not too difficult.Banks only need to attract the public by providing promos or providing products that are easy to terms and conditions.

Based on Bank Indonesia Circular No. 6/23 / DPNP dated May 31, 2004 the funds entrusted by the community to the bank can be in the form of demand deposits, savings deposits. After 
fundraising, bank wouldi redistribute these funds to the public or better known as credit (Kasmir 2001).Credit is the bank's most important activity in generating profits (Dendawijaya 2003). Like financing theory Karim (2004) stated that one source of funds that can be used for financing is own capital, so that the greater the available funding sources, the bank will be able to channel financing in the larger maximum limit, especially in the agricultural sector.

\section{Inflation and Islamic Perspective}

The inflation definition is as varied as we can find in the economic literature. This diversity of definitions occurs because of the extent of the influence of inflation on various sectors of the economy. The close and broad relationship between inflation and various sectors of the economy gives rise to our differences in understanding and perception of inflation, as well as in formulating policies for the solution. However, in principle there are still some unity of view that inflation is a phenomenon and economic dilemma. Inflation is a condition that indicates the weakening of purchasing power which is followed by the decreasing real value of a country's currency.

According to Islamic economists, inflation is very bad for the economy because of the following four thing. First, it causes disruption to the function of money, especially to the function of savings (saving value), the function of upfront payments, and the function of unit calculations. Second, as a result of the inflation burden, people must break away from money and financial assets. Third, there are weakening the spirit of the community to save (the decrease in marginal propensity to save) and increasing tendency to shop, especially for non-primary and luxury goods. 
Fourth, direct investment in unproductive things such as the accumulation of wealth in the form of land, buildings, precious metals and foreign currencies as well as sacrificing productive investments such as agriculture, industry, trade and transportation (Karim 2010).

\section{Relation of of Inflation Levels to Financing}

Inflation is a general increase in the price of goods / commodities and services continuously in a certain period. Inflation can cause disruption to the savings function (value of deposits). Islamic anks as one of the players in the banking finance industry are not spared from the effects of inflation. The close and broad relationship between inflation and various economic sectors gave rise to our differences in understanding and perception of inflation, as well as in formulating policies for the solution. However, in principle there are still some unity of view that inflation is a phenomenon and economic dilemma. Inflation is a condition that indicates the weakening of purchasing power which is followed by the declining real value of a country's currency (Khalwaty 2000).

Inflation can cause a high risk of default. This risk will increase non-performing financing of Islamic banking. So that when the inflation rate is high, the bank will be very careful in distributing financing. In addition, inflation can also put pressure on Islamic banks in terms of raising funds from the public, rising and falling inflation will affect the level of public saving, so that it will affect the financing of Islamic banks

\section{Non Perfoming Loans}

In the banking business, the most profit is from financing or providing credit to the public. Although financing is one of 
the sources of bank income, financing also has risks, namely the occurrence of non-performing financing such as substandard loans, doubtful financing and bad financing. Non Performing Financing is a credit that is classified as doubtful and loss. The terms doubt and loss here refer to the Bank Indonesia provisions adopted by Indonesian banks. Whereas according to Suhardjono (2002) NPF (Non Performing Financing) is a condition where the customer is unable to pay part or all of his obligations to the bank as agreed. From some of the notions of Non Performing Financing (NPF) above it can be concluded that Non Performing Financing is a problematic financing which is categorized as loss.

\section{Previous Research}

Beik (2013) found that agricultural financing is significantly affected by NPF, the amount of TPF and equivalent rate of financing (ERP).Second, in the long term, the variables that influence agricultural financing are SBI interest rates (SBSBI), SBIS bonuses, TPF amounts, equivalent rate of agricultural sector financing (ERP), the value of returns received by third party funds or savings customers (ERDPK) and credit interest rates (SBK). While the variables that have no significant effect on the long term are NPF and Inflation.

Dahlan (2015) stated that effect of SBIS bonus levels and inflation rates on the distribution of Islamic bank financing in Indonesia Independent variables: SBIS bonuses and inflation Dependent variable: Islamic Bank SBIS Bonus financing and inflation have a negative relationship to the distribution of Islamic Bank financing in Indonesia and have a significant influence on the distribution of Islamic Bank financingin Indonesia. 
Research Framework

\section{Graph. 1}

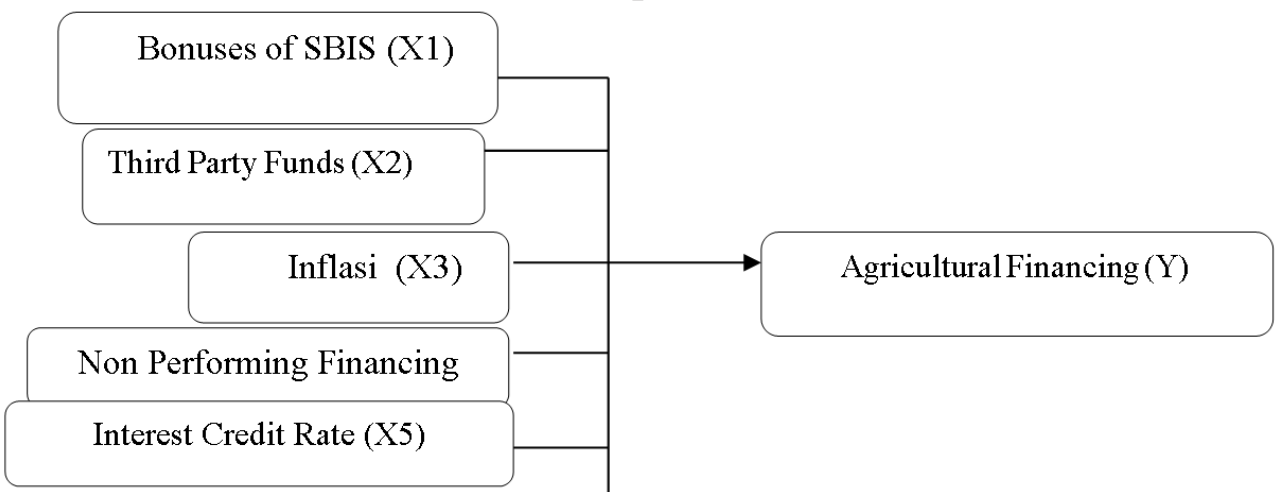

Source : (Beik 2013)

\section{METHODS}

\section{Research Variables}

The definition of the research variable is something in the form of what is determined by the researcher to be studied until information is obtained about it, then drawn conclusions. In this study.

Independent variables are variables that influence or cause changes or the occurrence of the dependent variables (Sugiyono 2004). In this study the independent variables are: bonuses of Bank Indonesia Sharia Certificate (SBIS), Third Party Funds (TPF), inflation, Non Performing Financing (NPF), and Credit Interest Rate. Dependent or dependent variables are variables that are affected or which are due to the existence of independent variables (Sugiyono 2004). In this study the dependent variable is the financing of Islamic banks in the agricultural sector in Indonesia. 


\section{Population and Sample}

Dajan (1996) stated that the population is the whole element which has one or more of the same characteristics or characteristics. The population used in this study is a report on Islamic banking statistics. The sample according to Sugiyono (2004) is part of the number and characteristics possessed by the population. The sample taken in this research is a report on Islamic banking statistics for three years from 2014-2016. In this study the authors used convenience sampling, namely the sample members that selected based on the ease of obtaining data to measure

\section{Data Collection Method}

The data obtained in this study is secondary data derived from literature / other sources from inside and outside of Islamic banking, while data collection techniques are as follows Secondary data Secondary data is data obtained from other parties (already available) and used for other research. The data is in the form of Islamic banking statistics taken monthly from 2014-2016 published in the Financial Services Authority, then can also be from Bank Indonesia publications. This paper occupies reading, citing materials relating to research from relevant sources and internet database.

\section{Data Analysis Model}

To examine the influence model and the relationship of the independent variables which are more than two variables to the dependent variable, multiple linear regression method is used (Ghozali, 2006). Before performing multiple regression analysis, this method requires to perform a classic assumption test in order to get good results. 


$$
\mathrm{Y}=\mathrm{a}+\beta 1 \mathrm{SBIS}+\beta 2 \mathrm{DPK}+\beta 3 \mathrm{INF}+\beta 4 \mathrm{NPF}+\beta 5 \mathrm{SBK}+\mathrm{e}
$$

Information :

$\mathrm{Y}=$ Agricultural Financing

a $=$ constant $\beta 1-\beta 5=$ Parameter Coefficient

$\mathrm{X} 1=$ Bonus SBIS

$\mathrm{X} 2=$ Third Party Funds (TPF)

$\mathrm{X} 3$ = Inflation

$\mathrm{X} 4$ = Non-Performing Financing (NPF)

$\mathrm{X} 5=$ Credit Interest Rate $(\mathrm{SBK})$

$\mathrm{E} \quad=$ Disturbing Variables

\section{Classic Assumption Test}

1. Normality Test.

This normality test aims to test whether the regression model of the dependent variable and the independent variable has a normal distribution or not. A good regression model is a normal or near normal distribution with criteria if prob Jarque Bera $>\alpha(5 \%)$ is normally distributed.

2. Multicollinearity Test

Test Multicollinearity test aims to test whether in the linear regression model there is a correlation between period $t$ disturbing errors with confounding errors in the t- 1 period (Ghozali 2006). Multicollinearity means that there is a strong linear relationship between independent variables with one another in the regression model. A good regression model is that there is no linear correlation / strong relationship between the independent variables. If there is a symptom of multicollinearity in the regression model, then the regression model cannot appraise precisely so that the wrong conclusions about the variables studied are obtained. 


\section{Autocorrelation Test}

This test aims to test whether in a linear regression model there is a correlation between confounding errors in period $t$ with confounding errors in the period(Ghozali 2006)

4. Heteroscedasticity Test

This test aims to test whether in the linear regression model variance inequality occurs from residual one observation to anothern observation. To test the presence or absence of heteroscedasticity can be done by using the white test which is the probi-squared compared to $\alpha$ (5\%). If $\alpha<$ prob.chisquared is free from the problem of heteroscedasticity.

5. Model specification linearity test

This test is used to test the CLRM assumptions about linearity of the model, so it is often referred to as the linearity test of the model. In this study, the Ramsey Reset test is known as a general specification error test, with criteria if prob (F.statistics) $>\alpha(5 \%)$ there is no linearity problem (Utomo 2012).

\section{The Goodness of Fit Test}

a. Test F

This test aims to find out whether the independent variables simultaneously or together influence the dependent variable significantly. This test uses the $\mathrm{F}$ test by comparing probes (F statistics) with $\alpha(5 \%)$. If $\alpha>$ prob (F statistic) then the independent variables simultaneously affect the dependent variable.

b. $\mathrm{T}$ test The purpose of this test is to find out whether each independent variable significantly influences the dependent variable. This test is done by t-test or t-test, which is to 
compare prob (T statistics) with $\alpha$ (5\%). If prob. (T statistic) $<\alpha$ then a significant or independent variable partially affects the dependent variable.

\section{Determination Degree Test (R2)}

Test the degree of determination (R2) measures how far the ability of the model is formed in explaining the variation of independent variables. In this study using multiple linear regression, each independent variable partially and jointly influence the dependent variable stated with $\mathrm{R} 2$ to state the test of the degree of determination or how much influence the bonus variable of Bank Indonesia Sharia Certificate (SBIS), Third Party Fund ( TPF), inflation, Non Performing Financing (NPF), and Loan Interest Rates(SBK) on the variables of Islamic bank financing for the agricultural sector in Indonesia. The magnitude of the degree of determination is 0 to 1 . The closer to 0 , the smaller the effect of all independent variables on the value of the dependent variable (in other words the smaller the ability of the model to explain changes in the value of the dependent variable). Whereas if the test of the degree of determination approaches 1 then it can be said that the stronger the model is in explaining the variation of the independent variables on the dependent variable (Suharyadi \& Purwanto 2009)

\section{RESULTS AND DISCUSSION}

\section{The Profitability Development of Islamic Commercial Banks}

This study utilized computer software Eviews 10 as data processing tools to speed up the processing of results that can explain the variables with econometric analysis methods. The 
results and analysis of the tests that have been carried out as the table below :

\section{Table 1}

Results of Econometry Model Estimation

Islamic Bank Financing in the Agricultural Sector in Indonesia Year

2014-2016

$A G R L t=-6676.333+1388.459 S B I S t+0.023822 D P K t-322.4636 I N F t+$

8.197568NPFt -382.0858 SBKt $+e$

Prob $=(0.0033)(0.0160)(0.0033)(0.0002)(0.3680)$

Adj $R^{2}=0.820624$, DW- stat $=1.859638$, F-Stat $=33.02428$, Sig F-Stat $=$ 0.000000

Diagnosis Test $=$

1. Normality (Jarque Bera Test)

$\operatorname{Sig}\left(\mathrm{x}^{2}\right)=0.318404$

2. Linierity (Ramsey Reset Test)

Sig $(F)=0.1060$

3. Multicollinierity

Test of VIF

$\mathrm{SBIS}=1.647279 \mathrm{DPK}=1.608578 \mathrm{INF}=2.416544 \mathrm{NPF}=1.325917 \mathrm{SBK}$

$=2.070905$

Test of Klein

SBIS $=0.392938$ DPK $=0.378333$ INF $=0.586186$ NPF $=0.245805$

$\mathrm{SBK}=\mathbf{0 . 5 1 7 1 1 9}$

4. Heterocesdacity (WhiteTest)

Sig $\left(x^{2}\right)=0.0795$

5. Autocorrelation (Durbin Watson Test)

$\mathrm{DW}=\mathbf{1 . 8 5 9 6 3 8}$

Information $=$ significance level at $\alpha=0.05$

Source : Eviews 10 (data organized) 
1. Normality Test Results

The normality test used in this study uses the Jarque-Berra technique. The guideline used is if the jarque value is $>$ compared to the value of $\mathrm{X} 2$ table (with $\alpha 5 \%$ ) or probability $<0.05$ the data used is not normally distributed and vice versa, if the probability is $>0.05$, the data used is normally distributed.

Table 1 shows that all the variables are normally distributed or it can be said that the requirements for normality can be met. This can be seen from the value of J-B in this study of 2.288866 with a probability of 0.318404 . Where the probability must be greater than $\alpha=0.05$. Therefore, it cannot reject the null hypothesis and show that the research is normally distributed, so it can be said that the requirements for normality can be fulfilled.

2. Linearity Test (Model Specifications)

This test is usually designed to test whether an explanatory variable is suitable or not to be included in an estimation model. Ramsey test is used to examine whether the form is a linear or non-linear estimation model function.

Table 1 above illustrates the probability value is 0.1060 turns out to be greater than the error degree of $5 \%(0.05)$, meaning that there are no linearity problems. In other words, the form of the estimation model function in this study is linear.

3. Multicollinearity Test

Multicollinearity test aims to test whether there is a high or perfect correlation between independent variables or not free. A good regression model should not have correlation between independent variables. To detect the presence or absence of multicollinearity in the regression model, it can 
be seen from the value of Variance Inflation Factor (VIF) and the klein test, namely each R-squared of the independent variable compared to the overall R-Squared. The cutoff value commonly used to indicate the presence of multicollinearity is that if VIF $<10$ and each R-Squared variable less than $\mathrm{R}$-Squared, the model would be stated to have no symptoms of multicollinearity.

Table 1 above shows that the overall R-Squared is 0.846250 . $\mathrm{R}$-squared SBIS bonus is $0.392938(0.392938<0.846250)$. VIF value of third party funds (DPK) is 10.378333 (0.378333 $<0.846250)$, the VIF value of inflation is 20.586186 $(0.586186<0.846250)$, the VIF value of Non Performing Financing (NPF) is $245805(0.245805<0.846250)$. The VIF value of the loan interest rate $(\mathrm{SBK})$ is $0.517119(0.517119<$ $0.846250)$. Then all variables are free from multicollinearity problems based on the VIF test. .

4. Heterocedasticity test

Heteroscedasticity test aims to test whether in the linear regression model variance inequality occurs from residual one observation to another observation. If the residual variance from one observation to another observation remains, it is called homocedasticity and if different is called heteroscedasticity. To test the presence or absence of heteroscedasticity can be done by looking at the probi squared compared to $\alpha$. If $\alpha$ is smaller than prob-chi-squared then it is free from the problem of heteroscedasticity. Based on table 1 above shows that prob-chi-squared is $0.0795>0.05$, it indicates that it is free from the problem of heteroscedasticity. 


\section{Autocorrelation Test}

Autocorrelation test aims to test whether in a linear regression model there is a correlation between confounding errors in period $t$ with confounding errors in period t-1 (previously). The Durbin-Watson Test (D-W Test) is a very popular test to test whether there is an autocorrelation problem from the estimated empirical model. Following are the results of the autocorrelation test: Based on table 4.1 above, the value of Durbin Watson is 1.859638. Autocorrelation test seen from the value of Durbin Watson with a value between If $\mathrm{du}<\mathrm{d}$ $<4-\mathrm{du}$. Dl and du can be obtained from the table which is assumed by the amount of data and variables that produce $\mathrm{dl}=1.17$ and $\mathrm{du}=1.79$. Based on the results of the table above shows the value of Durbin Watson is 1.859638 (1.79 $<1.859638<2.21)$. This shows that there is no symptom of autocorrelation.

6. T test (partial)

After carrying out the overall regression coefficient test, the next step is to calculate the regressioncoefficients individually or $t$ test. The $t$ test is used to determine whether or not the influence of each independent variable individually (partial) on the dependent variable is tested at a significant level of 0.05 , the independent variable influences the dependent variable. The results of testing hypotheses with the $t$ test are as follows: 
Table 2

Validity Test of the Effect of Independent Variables

\begin{tabular}{ccccc}
\hline Variables & T & Sig t & Criteria & Conclusion \\
\hline SBIS & 1388.459 & 0.0033 & $<0.05$ & Significant \\
DPK & 0.023822 & 0.0160 & $<0.05$ & Significant \\
INF & -322.4636 & 0.0033 & $<0.05$ & Significant \\
NPF & 8.197568 & 0.0002 & $<0.05$ & Significant \\
SBK & -382.0858 & 0.3680 & $>0.05$ & Not Significant \\
\hline
\end{tabular}

Source : Eviews 10 (data organized)

a. T test of bonus variables for Bank Indonesia Sharia Certificates (SBIS)

The results obtained in the table 2 above, the bonus variable of Bank Indonesia Sharia Certificate (SBIS) statistically shows significant results at a probability value smaller than $\alpha(0.0033<0.05)$. While the coefficient variable for the bonus of Bank Indonesia Sharia Certificate (SBIS) is 1388,459 . It can be concluded that the bonus variable of Bank Indonesia Sharia Certificate (SBIS) partially has a significant positive effect on Islamic banking financing in the agricultural sector.

b. T test for third party fund variables

The results obtained in the table 2 above, third party fund variables statistically show significant results at a probability value smaller than $\alpha(0.0160<0.05)$. While the third party fund variable coefficient is 0.023822 . So it can be concluded that the variable of third party funds partially has a significant positive effect on Islamic banking financing in the agricultural sector by.

c. T test of the inflation variable

The results obtained in the table 2 above, the inflation 
variable statistically shows significant results at the probability value smaller than $\alpha(0.0033<0.05)$. While the inflation variable coefficient is -322.4636 . It can be concluded that the inflation variable partially has a significant negative effect on Islamic banking financing in the agricultural sector.

d. T test for Non Performing Financing (NPF) variables The results obtained in the table 2 above, the NPF variable statistically shows significant results on the probability value smaller than $\alpha(0.0002<0.05)$. While the NPF coefficient variable is 8.197568 . It can be concluded that the NPF variable partially has a significant positive effect on Islamic banking financing in the agricultural sector.

e. T test of the variable credit interest rate

The results obtained in the table 2 above, the variable loan interest rates statistically show insignificant results at the probability value greater than $\alpha(0.3680>0.05)$. While the variable interest rate coefficient is -382.0858 . So it can be concluded that the inflation variable partially does not affect the Islamic banking financing of the agricultural sector.

7. F test (simultaneous)

Calculated $\mathrm{F}$ test is used to test the simultaneous effect of independent variables on the next variable or to test the accuracy of the model (goodness of fit). If the independent variable has the effect simultaneously (together) on the dependent variable, the regression equation model is included in the criteria of fit or fit. Conversely, if there is no simultaneous effect then it is categorized as not suitable or 
non fit.

The $\mathrm{F}$ test is using probability (F.statistic) compared to $\alpha$. If $\alpha>$ probability (F.statistic) then the entire independent variable affects the dependent variable. Based on the processed data in table 2 above, it shows that the F test $\alpha(0.05)$ is greater than prob (F.statistik) which is $0.000000(0.05>0.000000)$, it can be concluded that independent variables simultaneously affect the dependent variables.

8. Test Adjusted R Square / Degree of Determination The determination coefficient or R Square (R2) is the amount of the independent variable contribution to the dependent variable. The higher the coefficient of determination, the higher the ability of the independent variable to explain variations in changes in the dependent variable.

The amount of Adjusted R-Squared is 0.820624 or $82.0624 \%$. It can be concluded that the effect of SBIS bonuses, Third Party Funds (DPK), Inflation, Non Performing Financing (NPF), and Loan Interest Rates (SBK) is $82.0624 \%$. While the remaining $17.9376 \%(100 \%-82.0624 \%)$ is influenced by other variables that not included in this study, such as SBI interest rates, the value of returns received by third party funds and others.

9. Multiple regression analysis

Based on the data presented in the table above in the Adjusted $\mathrm{R}$-Squared test, it will then be analyzed to determine the effect of SBIS, Non Performing Financing (NPF), Inflation, Third Party Fund (DPK) and Credit Interest (SBK) bonuses on financing of the agricultural sector by Islamic banking in Indonesia. Data management results with eviews 10 from the table above are: 
$\mathrm{AGRL}=\beta 0+\beta 1 \mathrm{SBIS}+\beta 2 \mathrm{DPK}-\beta 3 \mathrm{INF}+\beta 4 \mathrm{NPF}-\beta 5 \mathrm{SBK}+\mathrm{e}$

$$
\begin{gathered}
\mathrm{AGRL}=-6676,333+1388,459 \mathrm{SBIS}+0.023822 \mathrm{DPK}- \\
322.4636 \mathrm{INF}+8.197568 \mathrm{NPF}-382.0858 \mathrm{SBK}+\mathrm{e}
\end{gathered}
$$

The statistical interpretation of the regression equation model above is as follows:

1. The bonus variable value of Bank Indonesia Sharia Certificate (SBIS) is 1388,459 , it means that each 1 percent increase in bonus of Bank Indonesia Sharia Certificate (SBIS) will cause an increase in agricultural financing about 1388,459 billion, with the note that other variables are considered constant.

2. The variable value of Third Party Funds (TPF) is 0.023822 . It means that if each increase of 1 billion Third Party Funds (TPF) will cause an increase in agricultural financing by 0.023822 billion, with the note that other variables are considered constant.

3. If the inflation variable is -322.4636 and it means that if every 1 percent increase in inflation will cause a decrease in agricultural financing of 322.4636 billion, with the note that other variables are considered constant.

4. If the variable Non Performing Financing (NPF) is 8.197568 and it means that if every increase of 1 billion Non Performing Financing (NPF) will cause an increase in agricultural financing of 8.197568 billion, with the note that other variables are considered constant.

5. The results of the analysis stated that the Credit Interest Rate (SBK) did not affect the financing of Islamic banks in the agricultural sector. 


\section{Economic Interpretation}

The interpretation of the results of this study is as follows:

1. The influence of SBIS bonuses on Islamic Bank Financing in The Agricultural Sector

Based on the results of the time series data estimation, it shows that the bonus of Bank Indonesia Sharia Certificate (SBIS) affects the financing of Islamic banks in the agricultural sector by Islamic banks. The Bank Indonesia Sharia Certificate (SBIS) bonus has a positive and significant effect on the financing of Islamic banks in the agricultural sector in 2014 - 2016. This proves that the increase of SBIS bonus results contributes to the increase in the allocation of funds to finance the agricultural sector. With these conditions, the right and effective innovation of agricultural sharia financing products is needed. High dependence on natural conditions makes the agricultural sector a challenge for Islamic banking. This research finding is supported by previous research Beik (2013). The results showed a coefficient with a positive and significant direction.

2. The Influence of Third Party Funds (TPF) on the Islamic Bank Financing in the agricultural sector

Based on the estimation of time series data, it shows that Third Party Funds (DPK) affect the financing of Islamic banks in the agricultural sector. Third Party Funds (TPF) have a positive and significant effect on the Islamic bank financing in the agricultural sector 2014-2016. This means that Third Party Funds (DPK) contribute positively to the financing of Islamic banks in the agricultural sector. The greater the Third Party Fund (DPK) collected by Islamic 
banks, the more likely the bank will collect Third Party Funds (TPF) for financing activities.

3. The Influence of Inflation on The Islamic bank financing in the agricultural sector

Based on the estimation of time series data, it shows that inflation affects the financing of Islamic banks in the agricultural sector. Inflation has a negative and significant effect on the Islamic bank financing in the agricultural sector in 2014 - 2016. This means that there is a negative relationship between the distribution of financing of Islamic banks in Indonesia with the inflation rate. If inflation gets higher then the financing of Islamic banks in the agricultural sector tends to decline.

This research is supported by previous research conducted by Dahlan (2015) which showed a coefficient with a negative and significant direction.

4. The Influence of Non Performing Financing (NPF) on the of Islamic bank financing in the agricultural sector

Based on the results of the time series data, the estimation shows that Non Performing Financing (NPF) affects the financing of Islamic banks in thse agricultural sector. NonPerforming Financing (NPF) has a positive and significant effect on the financing of Islamic banks in the agricultural sector in 2014 - 2016.

This means that the increase in the number of Non-Performing Financing (NPF) will increase the amount of Islamic bank funds to the public.

5. The Influence of Loan Interest Rates (SBK) on Islamic bank financing in the agricultural sector 
Based on the estimation of time series data, it partially shows that the Loan Interest Rate (SBK) has a negative and insignificant effect on Islamic banks financing in the agricultural sector during 2014 - 2016. In other word, if Loan Interest Rate (SBK) rises or falls, the Islamic bank will continue to finance the agricultural sector.

\section{CONCLUSION}

In conclusion, it can be concluded that variable of Indonesia Sharia Certificates (SBIS), Non Performing Financing (NPF), inflation, Third Party Funds, and Loan Interest Ratestogether influence the financing of Islamic banks in the agricultural sector in Indonesia . Bonus of Bank Indonesia Sharia Certificates, Third Party Funds (DPK), and Non Performing Financing (NPF) have a significant positive effect on the financing of Islamic banks in the agricultural sector in Indonesia, which means that any increase in the those variables will increase the financing of Islamic banks in the agricultural sector. Inflation has a significant negative effect on the financing of Islamic banks in the agricultural sector, which means that if inflation increases, the financing of the agricultural sector tends to decline. Loan Interest Rates (SBK) has an insiginificant influence on financing in the agricultural sector, which means that if loan interest rates increase or decrease there is no effect on financing in the agricultural sector. Based on the Adjusted R-Squared test, it can be concluded that the effect of bonuses on Bank Indonesia Sharia Certificates (SBIS), Non Performing Financing (NPF), inflation, Third Party Funds, and Loan Interest Rates is $82.0624 \%$, then the remaining portion 
$17.9376 \%$ influenced by outside research model variables.

The existence of Islamic banks is needed by the people of Indonesia, especially who has small and weak economies like in the agricultural sector. Therefore financing must be considered and given to fully support the middle and small communities so they can get easy business capital access. This research encourage Islamic banking practitioners to pay more attention to Islamic bank financing for farmers in Indonesia. In addition, the level of Non Performing Financing (NPF) which tends to increase needs to be a concern in order to increase productivity and effectiveness.

\section{REFERENCE}

Ashari, S., 2005. Prospek Pembiayaan Syariah Untuk Sektor Pertanian. Forum Penelitian Agro EKonomi, 23(2), p.132.

Beik, I.S., 2013. Analisis Faktor-Faktor Yang Mempengaruhi Pembiayaan Syariah Untuk Sektor Pertanian di Indonesia. Agro Ekonomi, 2.

Dahlan, I.A.R., 2015. Pengaruh Tingkat Bonus SBIS dan Tingkat Inflasi Terhadap Penyaluran Pembiayaan Bank Syariah di Indonesia. Equlibrium, 3(1), p.65.

Dajan, A., 1996. Pengantar Statisitk Jilid II, Jakarta: PT. Pustaka LP3ES.

Dendawijaya, L., 2003. Manajemen Perbankan ed. 2., Jakarta: Salemba Empat.

Ghozali, I., 2006. Aplikasi Analisis Multivariate Dengan Progam SPSS, Semarang: Universitas Diponegoro.

Herman, D., 2006. Pasar Finansial dan Lembaga-lembaga 
Finansial, Jakarta: Bumi Aksara.

Karim, A., 2010. Analisis Fiqh dan Keuangan, Jakarta: Raja Grafindo Persada.

Karim, A., 2004. Bank Islam: Analisis Fiqh dan Keuangan, Jakarta: Raja Grafindo Persada.

Kasmir, 2001. Bank dan Lembaga Keuangan Lainnya, Jakarta: Raja Grafindo Persada.

Kasmir, 2010. Dasar-Dasar Manajemen Perbankan, Jakarta: Rajawali Pers.

Khalwaty, 2000. Inflasi dan Solusinya, Jakarta: Gramedia Pustaka Utama.

Muhammad, 2005. Manajemen Pembiayaan Bank Syariah, Yogyakarta: UPP AMO YKPN.

Nasution, Z., 2006. Model Pembiayaan Syariah Untuk Sektor Pertanian. Jurnal Ekonomi dan Perbankan Syariah, 3(2), pp.7-9.

Otoritas Jasa Keuangan, 2010. Statistik Perbankan Syariah,

Prayitno, H., 1985. Pembangunan Ekonomi Pedesaan, Yogyakarta: Liberty.

Purwaningsih, 2017. Ekonomi Pertanian, Surakarta: UNS Press.

Rivai, V., 2007. Bank and Financial Institution Management Conventional and Syaria System, Jakarta: Raja Grafindo Persada.

Sinungan, M., 1993. Manajemen Dana Bank, Jakarta: Bumi Aksara.

Sugiyono, 2004. Statistika Untuk Penelitian, Bandung: Alfabeta.

Suhardjono, M.K., 2002. Manajemen Perbankan, Yogyakarta: 
BPFE-YOGYAKARTA.

Suharyadi \& Purwanto, 2009. Statistika Untuk Ekonomi Dan Keuangan Modern, Jakarta: Salemba Empat.

Utomo, P., 2012. Buku Praktek Komputer Statistik II Eviews., Surakarta: Universitas Muhammadiyah Surakarta. 